\title{
Catalina de Lancaster, la Orden de Predicadores y la reginalidad: las políticas conventuales
}

\section{Catherine of Lancaster, the Order of Preachers, and Queenship: Monastic Policies}

María del Mar GRAÑA CID

Doctora en Historia Medieval. Profesora Titular.

Departamento de Sagrada Escritura e Historia de la Iglesia, Facultad de Teología, Universidad Pontificia Comillas, c/ Universidad Comillas, 3-5, 28049 Madrid, España.

C. e.: mar.grana@comillas.edu. ORCID: http://orcid.org/0000-0001-6706-2298

Recibido: 25/05/2016. Aceptado: 04/11/2016

Cómo citar: Graña Cid, María del Mar, «Catalina de Lancaster, la Orden de Predicadores y la reginalidad: las políticas conventuales», Edad Media. Revista de Historia, 2017, n 18, pp. 75-100 DOI: https://doi.org/10.24197/em.18.2017.75-100

Resumen: La fundación de conventos y monasterios y las políticas desarrolladas en torno a estos espacios de espiritualidad constituyen una interesante herramienta de conocimiento del oficio regio femenino en su concepción y praxis. Analizamos en esta clave las actuaciones de Catalina de Lancaster, con interesantes diferencias entre sus etapas como reina consorte y regente. Ello permite mostrar su concepto como "mujer política" arraigada en la noción de un principio político femenino, así como los frentes de acción que desarrolló en este ámbito y que no fueron únicamente simbólicos o propagandísticos.

Palabras clave: Catalina de Lancaster; Reginalidad; Orden de Predicadores; Fundaciones religiosas.

Abstract: A knowledge of the foundation of convents and monasteries and the policies surrounding these spaces of spirituality proves an interesting stepping-stone towards a better knowledge of both the concept and practice of queenship. The work of Catherine of Lancaster is analyzed in this light, and the differences between her periods as queen consort and queen regent are revealed. An insight is provided into the queen as a 'female politician', rooted in the notion of a 'female policy', and into her action fronts in this area, which were more than merely symbolic or propagandistic.

Keywords: Catherine of Lancaster; Queenship; Order of Preachers; Religious Foundations.

Sumario: 1. Ser reina y promover espacios de espiritualidad. 1.1. Consorte y fundadora. 1.2. Regente de Castilla. 1.3. El vínculo con la Orden de Predicadores. 2. Conventos y monasterios en la política del reino.

Este trabajo se ha realizado en el marco del Proyecto de Investigación Paisajes espirituales. Una aproximación espacial a las transformaciones de la religiosidad femenina medieval en los Reinos Peninsulares en la Edad Media (siglos XII-XVI), HAR2014-52198-P. 
La reflexión sobre el oficio regio femenino, la capacidad de poder de las reinas y los contenidos y alcance de sus actuaciones ${ }^{1}$ es necesaria para clarificar la historia de la política y de lo político. Una de sus dimensiones más importantes fue la promoción religiosa y cultural, fenómeno complejo y susceptible de acercamientos diversos. En esta ocasión analizaremos el peso que pudo tener en la política reginal la fundación de espacios de dedicación a la espiritualidad. Afirmar que la religión constituyó un puntal de la reginalidad podría parecer redundante dado que evidentemente lo fue de la monarquía, pero la peculiar posición de las reinas en los ámbitos del poder dota a sus actuaciones de contenidos específicos y aconseja un tratamiento diferenciado, al menos como opción metodológica primera. La promoción de conventos y monasterios no fue sólo una manifestación de devoción o piedad. Espacios materiales y simbólicos, concretaban y proyectaban ideologías, aportaban un contingente humano de apoyo y mediación terrestre y celeste, constituían enlaces de redes sociopolíticas vehiculares, de cohesión y de influencia, incidían en sus contextos de implantación, y brindaban a sus fundadoras diversas posibilidades de promoción social y capacidad operativa. Entre otras cuestiones.

Nos acercaremos en clave política a la destacada actividad conventual de una reina de Castilla, doña Catalina de Lancaster ${ }^{2}$. En una doble dimensión: como manifestación y fundamento de lo que entendió era su papel reginal y en relación con la corona y la gestión del reino, intentando valorar su grado de trascendencia desde la perspectiva de la orientación religiosa de los reinados en el cambio de dinastía.

\section{SER REINA Y PROMOVER ESPACIOS DE ESPIRITUALIDAD}

Doña Catalina puso su interés religioso en las órdenes mendicantes, sobre todo la dominica, y destacó como reina fundadora y señora de espacios de espiritualidad, aunque su comportamiento varió como consorte o regente.

\footnotetext{
${ }^{1}$ Aspectos comprendidos en el concepto "reginalidad". Silleras Fernández, N., «Queenship en la Corona de Aragón en la Baja Edad Media: estudio y propuesta terminológica», La Corónica: A Journal of Medieval Hispanic Languages, Literatures \& Cultures, 2003, vol. 32, $\mathrm{n}^{\circ}$ 1, pp. 119133.

${ }^{2}$ Echevarría, A., Catalina de Lancaster. Reina regente de Castilla (1372-1418), Hondarribia, Editorial Nerea, 2002, p. 80; Id., «Dinastía: reinas mecenas en los albores del Humanismo», en Serrano de Haro, A.; Alegre, E. (coords.), Retrato de la mujer renacentista, Madrid, UNED, 2012, pp. 67-90; Olivera Serrano, C., «Felipa y Catalina de Láncaster: religiosidad y relato historiográfico», Anuario de Estudios Medievales, 2016, 46/1, pp. 361-391. Planteé esta metodología en Graña Cid, Ma M., «Religión y política femenina en el Renacimiento castellano. Lecturas simbólicas de Teresa Enríquez», en Lorenzo, J.; Cerrada, A. I. (eds.), De los símbolos al orden simbólico femenino (ss. IV-XVII), Madrid, A. C. Al-Mudayna, 1998, pp. 145-172.
} 


\subsection{Consorte $y$ fundadora}

Llevó a cabo sus fundaciones sólo cuando era consorte y únicamente establecimientos de la Orden de Predicadores. Su obra tuvo marcada connotación femenina. Comenzó en 1394 por un monasterio de monjas, San Pedro Mártir de Mayorga ${ }^{3}$. Su segundo proyecto, ubicado en el "locus" mariano de Santa María de Nieva, se concretó como convento de frailes en $1399^{4}$.

Estas fundaciones constituyeron una declaración de principios en su concreta orientación humana y devota. Con un notable carácter personalista, la reina las utilizó para singularizarse, hacerse propaganda y abrirse espacios de acción autónoma y ejercicio del poder situándose en una posición no subordinada ni secundaria respecto al rey. De algún modo, su importante papel como "fundadora dinástica" en la unión de las dos ramas en conflicto y como heredera al trono se tradujo en su actuación como "reina fundadora" de monasterios y conventos. Así manifestó su peculiar dignidad regia mientras ampliaba sus capacidades y espacios de acción y delimitaba ámbitos bajo su dominio empleando herramientas al alcance de las reinas y aristócratas: patronato y señorío.

El "ser reina" figura ligado a su actividad promotora de espacios sagrados, que inició tras su pleno acceso al trono en 1393. Con el impulso de dos templos de advocación femenina en Nieva se vinculaba a un lugar de aparición de la Virgen y subrayaba simbólicamente la genealogía femenina de Cristo. Mientras construía una iglesia magnífica en honor a María, reedificó una ermita dedicada a Santa Ana. Con ello ratificaba su condición de reina de Castilla y visibilizaba su cambio de obediencia papal ${ }^{6}$. El estatus privilegiado de su creación muestra su afán de publicitarse y ejercer el poder. Solicitó a Clemente VII un prior y seis capellanes exentos de la jurisdicción parroquial para atender el culto. Denominados "capellanes de la reina", proyectaron su buena imagen en el lugar, convertido en foco de peregrinaciones. Su pretensión de lograr visibilidad a escala peninsular se plasma en la petición de que pudiesen recabar limosnas para la capilla por los reinos hispanos. El papa aceptó y favoreció la afluencia

\footnotetext{
${ }^{3}$ López, J., Tercera parte de la historia general de Sancto Domingo y de su Orden de Predicadores, Valladolid, por Francisco Fernandez de Córdoua, 1613, libro I, p. 365; Aniz Iriarte, C; Callejo de Paz, R., Real monasterio de San Pedro Mártir de Mayorga. Fundación de la reina Catalina de Lancaster, Salamanca, San Esteban, 1994.

${ }^{4}$ López, op. cit., libro II, pp. 7-8; Yuramí, A. M., Historia de la aparición de la taumaturga ymagen de Nuestra Señora la Soterraña de Nieva, Madrid, Galileo, 1995, p. 54; Arnanz Ruiz, C., Santa María la Real de Nieva, Santa María la Real de Nieva, Ayuntamiento, 1972; Sánchez Sierra, A., El monasterio de Santa María la Real de Nieva, Segovia, Caja de Ahorros y Monte de Piedad de Segovia, 1983.

${ }^{5}$ Jardin, J.-P., «Le rôle politique des femmes dans la dynastie Trastamare», e-Spania, 2006, p. 3.

${ }^{6}$ Suárez Bilbao, F., Enrique III (1390-1406), Palencia, Diputación Provincial-La Olmeda, 1994, p. 81.
} 
de fieles concediendo indulgencias ${ }^{7}$. Esta singularización como personaje público se remató en dimensión política al crearse en el lugar una villa nueva, Santa María la Real de Nieva, exenta de la comunidad segoviana y vinculada a la corona a través de la reina como señora. A lo largo de un proceso culminado en 1395 enfatizó su posición de poder como patrona, defensora y edificadora de la iglesia y como señora de la villa. Si lo primero se lo reconocía Benedicto XIII, Enrique III le otorgaba autoridad y poderío para organizar y dirigir el asentamiento de pobladores haciendo "a toda su voluntad" lo que ella quisiese como señora del lugar, gestión poblacional que completó con la económica de las iglesias como principal administradora ${ }^{8}$.

En 1394 comenzó a crear espacios de vida religiosa fundando el monasterio de Mayorga en la misma línea de promoción personal y femenina. Fue la única responsable al asumir la edificación y dotación y buscó la novedad: en la villa no había instalación dominica masculina ni otros establecimientos femeninos y concretó un planteamiento reformista situado bajo la todavía poco habitual advocación de San Pedro Mártir ${ }^{9}$. Acaso esta iniciativa tuviese que ver con el inicio de su apoyo a las dominicas de Toledo en 1392, pero no se documentan conexiones.

Las escasas noticias parecen reflejar un proyecto de cambio cifrado en el ascetismo $^{10}$. Aunque no se debió abrazar la pobreza radical, hubo gran austeridad: la dotación fue modesta y las monjas usaban hábitos de lana grosera y camas pobres. Fueron radicales en la clausura -no tenían redes ni locutorios donde recibir visitas-, el ayuno, el silencio, la oración continua y la disciplina física ${ }^{11}$. La fundación de la reina se contraponía a "la Claustra", fenómeno de relajación religiosa dominante en la Castilla del siglo XIV en el que las monjas disfrutaban de propiedad privada y no observaban clausura. Sintonizaba con los afanes del maestro general de la Orden de Predicadores, fray Raimundo de Capua, cuando tampoco los frailes habían iniciado su reforma en Castilla ${ }^{12}$.

La fundación de la reina ofrece algunos rasgos comunes con otro cenobio muy próximo y con el mismo título original, San Pedro Mártir de Benavente ${ }^{13}$. Debía funcionar en 1348, pero sufrió algún cambio interno reflejado en la nueva

\footnotetext{
${ }^{7}$ Yuramí, op. cit., pp. 56 y 274, nota 35; Nogales Rincón, D., La representación religiosa de la monarquía castellano-leonesa: la capilla real (1252-1504), (Tesis Doctoral inédita), Universidad Complutense de Madrid, 2009, pp. 1813-1814.

${ }^{8}$ Sánchez Sierra, op. cit., pp. 117-121, 129-130; Arnanz Ruiz, op. cit., p. 55.

${ }^{9}$ Solo se conserva una copia de la bula fundacional más las noticias recogidas en las crónicas. López, op. cit., libro I, p. 365; Aniz, C.; Callejo, R., op. cit., pp. 82, 89.

${ }^{10}$ López, op. cit., libro I, pp. 365-366; Medrano, M. J. de, Historia de la Provincia de España de la Orden de Predicadores. Segunda parte, Madrid, 1729, libro II, p. 517.

${ }^{11}$ López, op. cit., libro I, p. 365; Medrano, Segunda, libro II, p. 517; Aniz, C.; Callejo, R., op. cit., pp. 89-91.

${ }^{12}$ Nieva Ocampo, G., «'Reformatio in membris': conventualidad y resistencia a la reforma entre los dominicos de Castilla en el siglo XV», En la España Medieval, 2009, vol. 32, pp. 300-301.

${ }^{13}$ López, op. cit., libro I, p. 336.
} 
advocación de Sancti Spiritus en 1350; en 1378 hubo una nueva fundación o refundación sin que esté clara la recuperación del nombre anterior. Gozó de una buena dotación ${ }^{14}$ a cuyo nivel no debió estar la modesta fundación de Mayorga. La historiografía dominica ha subrayado su rigor y no está claro si en algún momento de su historia gozó de propiedad privada. Pero estas dos fundaciones tuvieron más en común que las vinculadas a otras reinas. Beatriz de Portugal y Leonor de Alburquerque promovieron dominicas después de doña Catalina favoreciendo un modelo monástico suntuoso y con intenciones residenciales definitivas en Sancti Spiritus de Toro ${ }^{15}$ y Medina del Campo ${ }^{16}$ respectivamente.

Catalina de Lancaster se significaba creando un establecimiento de radicalidad ascética y patrimonio modesto en un lugar que no era de su señorío. Sin duda, Benavente, villa de la que era señora precisamente desde 1394, estaba copada por fundaciones religiosas. Pero sorprende que se decidiese por otra tan próxima como Mayorga, cabeza del recién creado condado y en manos del infante Fernando. Era una villa de tradicional señorío reginal que había interesado a Pedro ${ }^{17}$, al que quizá quiso rememorar con la advocación de San Pedro Mártir ${ }^{18}$. Allí se hacía visible la reina creando un monasterio junto al que edificó unas dependencias para su uso decoradas con su escudo de armas ${ }^{19}$. El interés de proyección de presencias se perfila con fuerza y llama la atención que estos enclaves monásticos sirviesen a modo de contrapeso de ámbitos de influencia de los parientes regios: si doña Catalina era señora de Benavente y fundaba en Mayorga, su cuñado y señor de ésta tenía a su vez una cuñada monja en Benavente, Leonor de Castilla, hermana de Leonor de Alburquerque, que debió profesar por aquellas fechas ${ }^{20}$. Este equilibrio de proyecciones, ¿reflejaba una presencia política equiparada por parte de la reina y del infante?, ¿un afán por imponerse una u otro que ya estuviese reflejando la que sería difícil coexistencia política de ambos ${ }^{21}$ ? La falta de datos impide precisar las líneas concretas de incidencia. Nos preguntamos si el cambio de advocación del monasterio benaventano pudo obedecer a la presencia de doña Leonor, que al trasladarse poco después al monasterio de Toro hizo que adoptase el mismo

\footnotetext{
${ }^{14}$ AHN, Clero, leg. 8180; Medrano, op. cit., libro I, p. 199.

15 AHN, Clero, libro 18.314, pp. 13-14; Olivera Serrano, C., Beatriz de Portugal. La pugna dinástica Avís-Trastámara, Santiago de Compostela, CSIC, 2005, pp. 391ss.

${ }^{16}$ Medrano, M. J. de, Historia de la Provincia de España de la Orden de Predicadores. Tercera parte, libro I, pp. 64-67, 69, 71; López, op. cit., libro II, p. 33.

${ }_{17}^{17}$ Aniz, C.; Callejo, R., op. cit., pp. 55-56.

${ }^{18}$ Sobre esta posible intención de la reina y su coincidencia con Benedicto XIII, promotor de un panteón en la iglesia del mismo nombre en Calatayud: Echevarría, A., «Dinastía», p. 75. La bula menciona la devoción personal de la reina por este santo: Aniz, C.; Callejo, R., op. cit., p. 14.

${ }_{19}$ Pérez Vidal, M., «"Uniformitas vs diversitas” en los monasterios femeninos de la Orden de Predicadores en Castilla (siglos XIII-XV)», Territorio, Sociedad y Poder, 2013, vol. 8, p. 145.

${ }^{20}$ Hija bastarda del infante Sancho de Castilla. Medrano, Tercera, libro I, pp. 198-199; Aniz, C.; Callejo, R., op. cit., p. 84.

${ }^{21}$ Jardin, op. cit., p. 11.
} 
nombre. ¿Por la propiedad privada? Con ella se movilizó la red de influencia familiar, facilitada por la concesión de donaciones particulares dado que aquellas monjas sí poseían bienes ${ }^{22}$. Fuese de un modo u otro, al final quedó la única "presencia" religiosa de doña Catalina en la zona. Sumada a su señorío sobre Benavente, dibujaba un cuadro de incidencia reginal y realenga apoyada en la red de implantación dominica. Con la fundación de Mayorga completaba el triángulo conventual Valladolid-Toro-Benavente-León que la monarquía castellana -reyes, reinas y otros miembros de la familia real-impulsaba desde el siglo XIII.

Poco después intensificaba la reina su promoción dominica fundando en Nieva un convento de frailes. El obispo de Segovia otorgaba licencia y cedía su jurisdicción a la orden en 1399 por cumplir servicio de Dios y de la dicha señora reyna. Doña Catalina protagonizó el proceso fundacional con total autonomía como señora de la villa y patrona del convento, al que denominaba "mi monasterio" y cuyos frailes eran capellanes suios ${ }^{23}$. No era un proyecto reformista y le otorgó pingües donaciones ${ }^{24}$. Surgía conectado con otra fundación vinculada a la corona desde el siglo XIII, Santa Cruz la Real de Segovia: núcleo originario de los dominicos hispanos, la reina acababa de favorecerlo con la cesión de una huerta que había comprado a la catedral ${ }^{25}$. Fue su prior quien recibió del obispo la posesión de Nieva. Por lo demás, doña Catalina determinó que su nueva fundación fuese uno de los lugares de su memoria perpetua ${ }^{26}$.

Es posible percibir en estas creaciones la conciencia de la reina como "mujer política" y su interés por plasmar un principio político femenino. Contribuyen a explicarlo su peculiar posición dinástica y la función que asumió al casarse con Enrique III, pero también las transformaciones mentales de su tiempo, un siglo XIV que estaba asistiendo a la forja de modelos femeninos de activismo público deudores de una reformulación de la feminidad. Paso primero en el origen de la conciencia feminista que eclosionaría con la obra de Christine

\footnotetext{
${ }^{22}$ AHN, Clero, libro 18.314, pp. 999, 111; Castillo, H. del, Segunda parte de la Historia general de Santo Domingo y de su Orden de Predicadores, Valladolid, Francisco Fernandez de Cordoua, 1592, libro II, fol. 60r; Medrano, Tercera, libro I, p. 199. El monacato dominico era de gran heterogeneidad en este momento. Pérez Vidal, op. cit., pp. 150-151.

${ }^{23}$ Yuramí, op. cit., pp. 88 y 161.

${ }^{24}$ Sánchez Sierra, op. cit., p. 29. Este autor edita los principales documentos, custodiados en el Archivo Histórico Nacional. El convento se reformó en 1435. Nieva, op. cit., p. 300

${ }^{25}$ López, op. cit., libro II, pp. 8, 12; Medrano, Tercera, libro I, p. 29; Nieva Ocampo, G., «Los dominicos en Castilla. La génesis de una corporación privilegiada en la Baja Edad Media», en Nieva, G.; Benito, S. G. A.; Navarro, A. M. (coords.), Servir a Dios y servir al rey: el mundo de los privilegiados en el ámbito hispánico (ss. XIII-XVIII), Salta, Mundo Gráfico, 2011, p. 36.

${ }^{26}$ Cañas Gálvez, F. de P., Colección diplomática de Santo Domingo el Real de Toledo. Documentos reales I (1249-1473), Madrid, Sílex, 2010, nº 116, p. 172; Corell Ruiz, L., Una copia del testamento de Catalina de Lancaster, Valencia, Instituto Valenciano de Estudios Históricos, 1952, p. 86 .
} 
de Pizan en el cambio de centuria. Fueron exponentes notables místicas como Brígida de Suecia o Catalina de Siena, que gozaron del apoyo dominico y alcanzaron proyección hispana ${ }^{27}$.

Femenina fue la primera creación de la reina, toda una declaración de intenciones en su pretensión de novedad y cambio. Bajo titulación femenina fue la segunda, proyecto de notable implicación política. Ambas visibilizaban el valor de lo femenino complementario o superior a lo masculino en advocación y concreción humana. La Orden de Predicadores era una institución que, al menos simbólicamente, se fundaba en la coparticipación de los sexos. La reina situaba su fundación femenina bajo una advocación masculina que remitía al carisma de saber y predicación de los frailes encarnándolo en monjas que por su rigor eran "sermones vivientes" 28 . Y fundaba un convento masculino bajo advocación femenina en un espacio de poder taumatúrgico femenino. Es notorio el peso de la feminidad en la iconografía de Nieva, tanto en número de figuras como en calidad temática, con énfasis en la palabra y el poder salvífico ${ }^{29}$. Sobre todo la figura de la Virgen, protagonista de esa fundación, aparece de forma peculiar en otros ámbitos relacionados con la reina. El muro externo de la capilla de Reyes Nuevos de la catedral de Toledo muestra escudos Plantagenet, evoca los alabastros ingleses y contiene una representación de María en el Nacimiento ajustada a las visiones de Santa Brígida ${ }^{30}$. La autobiografía (1401-1404) de Leonor López, valida de doña Catalina ${ }^{31}$, sintoniza con la vida de la santa en el peso político de la Virgen. Y no parece casual que el emblema heráldico de la reina, la piña -primera divisa regia femenina-, fuese de inspiración mariana ${ }^{32}$. Asociada a la maternidad y la fecundidad, simbolizaba la obra más importante de doña Catalina en cuanto madre portadora de legitimidad cuyo fruto iniciaba la nueva dinastía unificada, al igual que la Virgen era madre del Nuevo Hombre. Sin negar la impronta del modelo mariano de virtud que se destinaba a las reinas ${ }^{33}$, resuenan ecos del impulso que la devoción mariana, rompiendo

${ }^{27}$ Jiménez Duque, B., «Santa Brígida de Suecia (+1373) y los jerónimos españoles», Yermo, 1974, 12, pp. 3-14; Beltrán de Heredia, V., «Noticias y documentos para la biografía del cardenal Juan de Torquemada», Archivum Fratrum Praedicatorum, 1960, 30, pp. 53-148.

${ }^{28}$ Frecuente en la espiritualidad femenina. McNamara, J. A., «Living Sermons: Consecrated Women and the Conversion of Gaul», en Nichols, J. A; Shank, L. T. (eds.), Medieval Religious Women: Peaceweavers, Kalamazoo, Cistercian Publications, 1987, vol. 2, pp. 19-37.

${ }^{29}$ Sánchez Sierra, op. cit., pp. 87-91; Sánchez Sierra, A; Ramón Esteban, Á., Guía del monasterio de Santa María la Real de Nieva, Segovia, Asociación Cultural Santa María, 2004, pp. 16, 18.

${ }^{30}$ Morena, A. de la (coord.), Castilla-La Mancha, La España Gótica, Madrid, Encuentro, vol. 13, 1998, p. 105.

${ }^{31}$ Rivera Garretas, $\mathrm{M}^{\mathrm{a}} \mathrm{M}$., Textos y espacios de mujeres. Europa, siglo IV-XV, Barcelona, Icaria, 1990, pp. 159-178.

${ }^{32}$ Fernández de Córdova Miralles, Á., «El cordón y la piña. Signos emblemáticos y devociones religiosas de Enrique III y Catalina de Lancaster (1390-1418)», Archivo Español de Arte, 2016, 89, pp. 121-125; Olivera, «Felipa», p. 377.

${ }^{33}$ Jardin, op. cit., pp. 31-32. 
estos moldes culturales que subrayaban la pasividad, podía brindar a las mujeres como instrumento de auto-representación excelente y palanca de acción política $^{34}$.

Estos aspectos no sólo respaldaban la vigorosa actuación de la reina como fundadora y patrona. Porque doña Catalina asumió modelos de comportamiento de los titulares masculinos de la corona trazando líneas de continuidad al encarnar la herencia política castellana. Fueron notables sus sintonías con Pedro I y la entera dinastía desde el reinado inaugural de Fernando III. Aspectos de su conexión con su abuelo se han expuesto ya. Añadamos la decisión de iniciar una novedad reformista femenina sintonizando con la labor petrina en Santa Clara de Astudillo y Santa María de Tordesillas ${ }^{35}$ : sin seguir un plan a gran escala, sobre todo la segunda fue pionera en el franciscanismo castellano, hecho que la reina pudo querer plasmar en clave dominica. Un modelo de actuación diferente al de Juan I, cuyas grandes fundaciones reformistas fueron masculinas, de otras órdenes religiosas y con otra connotación política. Pero doña Catalina no promovió las fundaciones de su abuelo, posiblemente por un afán de desmarcarse de los Trastámara. De Tordesillas se habían apropiado los iniciadores de la dinastía, sobre todo doña Juana Manuel, al servicio de su política de legitimación ${ }^{36}$. Sólo en Astudillo hallamos una muestra de apoyo (1401) y a petición de las monjas: sin embargo, pese a defender al que consideraba su monasterio recordando que la abadesa era su tía, doña Catalina se limitaba a secundar al rey ${ }^{37}$, sin entablar una relación continuada ${ }^{38}$.

La identificación dinástica de la reina se plasmaba, precisamente, en su opción dominica. Fernando III ya había entablado un vínculo especial entre la corona castellana y la Orden de Predicadores al tomarla bajo su protección en todo su reino, vínculo al que Alfonso X confirió un carácter "nacionalista" castellano $^{39}$ y que continuarían los reyes posteriores hasta Alfonso XI para ser

\footnotetext{
${ }^{34}$ Børressen, K. E., Le madri della Chiesa. Il Medioevo, Napoli, M. D’Auria Editore, 1993, pp. 182-186; Graña Cid, $\mathrm{M}^{\mathrm{a}}$ M., «El nuevo Evangelio de las mujeres. Aportaciones mariológicas visionarias de Brígida de Suecia y Juana de la Cruz», ponencia en IV Colloquium Studium Medievale, Universitat de Girona, , julio 2010; Graña, «Religión», pp. 163-164.

${ }^{35}$ Graña Cid, $M^{a}$ M., «¿Favoritas de la corona? Los amores del rey y la promoción de la Orden de Santa Clara en Castilla (ss. XIII-XIV)», AEM, 2014, vol. 44, n 1, pp. 198-199.

${ }^{36}$ Martín Prieto, P., «Sobre la promoción regia de la orden franciscana en la Corona de Castilla durante el primer reinado Trastámara», Hispania Sacra, 2007, vol. 59, no 119, pp. 51-83. Doña Catalina no aparece en los catálogos del archivo monástico. González Cristóbal, M., Monasterio de Santa Clara de Tordesillas (1316-1936), Madrid, Patrimonio Nacional, 1987.

${ }^{37}$ Editado en Orejón Calvo, A., Historia del convento de Santa Clara de Astudillo, Palencia, Imprenta de la Casa de Expósitos y Hospicio Provincial, 1917, núms. 17-18, pp. 166-170.

${ }^{38}$ Se ha mencionado la posible comunicación epistolar entre la reina y las clarisas de Astudillo Echevarría, Catalina, p. 76-. En el verano de 2013 trabajé en el archivo del monasterio sin lograr encontrar esas cartas y sin que las monjas conociesen otro paradero posible.

${ }^{39}$ González, J., Reinado y diplomas de Fernando III, Córdoba, Monte de Piedad y Caja de Ahorros de Córdoba, 1983, vol. 2, n 152, p. 184; Aguadé Nieto, S., «Alfonso x y las órdenes mendicantes», Saxonia Franciscana, 1998, vol. 10, pp. 277-302; Graña Cid, M ${ }^{a}$ M., «The
} 
reactivado por Juan $\mathrm{I}^{40}$; entre ellos, la monarquía de Sancho IV se había significado por la inclinación pro-dominica, con gran peso específico del área benaventana y toresana en las políticas conventuales de la corona. Incluso, el gesto de transferencia de bienes diocesanos a una orden mendicante que la reina protagonizó con los dominicos de Segovia fue muy similar a otros de Fernando III y Alfonso $\mathrm{X}^{41}$. Al identificarse con la Orden de Predicadores, doña Catalina se presentaba como miembro titular de la rama dinástica legítima y, además de apartarse del programa de espiritualidad política pro-franciscana trazado por los primeros Trastámara, se diferenciaba de Enrique $\mathrm{III}^{42}$. Pero su identificación con los titulares de la corona iba más allá: con la promoción de un "locus" mariano y la pertinente fundación religiosa, no dejaba de emular la actuación de Alfonso XI y Juan $I^{43}$.

Lo expuesto estaba en línea con su indudable afán de poder, que encauzó por la vía del patronato a fin de abrirse espacios y presencias en ámbitos dependientes de otros y que pudo acabar señorializando en el marco de su interés general por ampliar sus dominios ${ }^{44}$. Pero no se trataba sólo de una cuestión de poder personal aunque la significación pública de este hecho, encarnada en una reina, fuese notable. Mediante sus proyectos religiosos plasmó además un principio político encarnado en un plan de convivencia urbana. En su forma más acabada se encuentra en Santa María la Real de Nieva, situada bajo la doble égida de la Reina del Cielo y la reina de Castilla como responsables del recto orden. Nueva población de origen religioso fundada en los valores políticos cristianos de paz y concordia sociales como garantes de la vida comunitaria civil -representada en la iconografía del convento- $-^{45}$, cuyo ordenamiento culminaría siendo regente. Se ha señalado que estos mismos valores alimentaron su proyecto de Mayorga, que ubicó intramuros para

Mendicant Orders and the Castilian Monarchy: The Reign of Ferdinand III», en García Serrano, F. (ed.), The Friars in Medieval Spain (en prensa).

${ }^{40}$ Juan I confirmó los documentos de protección a la orden de Sancho IV, Fernando IV y Alfonso XI en las cortes de Burgos (1379). Cañas, op. cit., no 3, 4, 8, 27, pp. 30-33, 36-37, 66-69.

${ }^{41}$ González, op. cit., n ${ }^{\circ}$ 257, pp. 298-300; Graña, «The Mendicant»; Casillas García, J. A., El convento de San Pablo de Burgos. Historia y arte, Salamanca, San Esteban, 2003, p. 41.

${ }^{42}$ Nieto Soria, J. M., «Franciscanos y franciscanismo en la política y en la corte de la Castilla Trastámara», AEM, 1990, vol. 20, pp. 109-132; Martín Prieto, op. cit., pp. 51-83.

43 Gómez Chacón, D. L, «Apariciones marianas y renovación monástica en la Castilla bajomedieval: Guadalupe y Santa María la Real de Nieva», en García de Cortázar, J. A; Teja, R. (coords.), Los monasterios medievales en sus emplazamientos: lugares de memoria de lo sagrado, Aguilar de Campóo, Fundación de Santa María la Real, 2016, pp. 211-244; Olivera Serrano, C., «Devociones regias y proyectos políticos: los comienzos del monasterio de San Benito el Real de Valladolid (1390-1430)», AEM, 2013, vol. 43, n 2, p. 803.

${ }^{44}$ Echevarría, Catalina, pp. 73-76.

${ }^{45}$ Caballero Escamilla, S., «El claustro de Santa María la Real de Nieva: imágenes y contextos», Cuadernos de Arte de la Universidad de Granada, 2011, nº 42, pp. 5-18; Molinero Rodríguez, F., La ciudad medieval de Santa María la Real de Nieva (Segovia), Segovia, Santa María la Real de Nieva, 2001, pp. 23-24. 
promover concordia social ${ }^{46}$. Este planteamiento político recibiría formulación teórica años después en la obra de Isabel de Villena, monja vinculada a la hija de doña Catalina, la reina de Aragón doña María de Castilla ${ }^{47}$.

Otro frente de acción fue el apoyo a comunidades ya instaladas en sus señoríos. Quizá favoreciese a las dominicas de Amasatrigo y su posible vínculo con Santo Domingo de Huete ${ }^{48}$. E impulsó, al menos, dos conventos franciscanos del XIII: el gótico inglés de San Francisco de Atienza sugiere su intervención reedificadora -irefundadora?- y benefició al de Molina de Aragón ${ }^{49}$. Esta labor pro-franciscana debió obedecer a la preexistencia de los conventos en sus dominios ${ }^{50}$ y no invalida su evidente preferencia dominica.

La reina buscó instrumentos de autoafirmación y maniobra en otros espacios religiosos entre los que destacó Santo Domingo el Real de Toledo, otro perpetuador de su memoria ${ }^{51}$ en cuya fundación había intervenido Pedro I (1364) y al que Juan I había otorgado protección (1380) ${ }^{52}$. Intensificó el vínculo con la corona porque allí profesaron María de Castilla, hija natural de don Pedro, y su madre Teresa de Ayala. La reina inició su trato de favor en 1392 apoyando económicamente la profesión de doña María, a quien se dirigía como mj tia, fija del rey don Pedro, calificado como my avuelo, que Dios de santo parayso; después haría lo mismo con doña Teresa. Fue secundada por Enrique III, que otorgó privilegios reconociendo su parentesco con Pedro I al denominar también a la primera my tia, fija del rey don Pedro ${ }^{53}$.

Era una relación política y personal importante. Doña Catalina quiso fomentarla para rehabilitar la memoria petrina y legitimar su línea bastarda, no sólo favoreciendo la supervivencia y afirmación de los Castilla ${ }^{54}$, sino creando este linaje sobre fundamentos femeninos. Creaba también un grupo de apoyo y respaldo. Esta fue nota característica de una reina que trabó importantes

\footnotetext{
${ }^{46}$ López, op. cit., libro I, p. 365; Aniz, C.; Callejo, R., op. cit., p. 82.

${ }^{47}$ Graña Cid, M ${ }^{a}$ M., «Mariología, reginalidad y poder en Isabel de Villena. Una teoría política femenina del siglo XV», Mirabilia, 2016, 22, pp. 96-127.

${ }^{48}$ No figura en la recopilación de actuaciones regias en AHN, Clero, libro 3274, fol. 88r.

${ }^{49}$ Herrera Casado, A., Monasterios medievales de Guadalajara, Guadalajara, Aache Ediciones, 1997, pp. 106, 110. Incluyó elementos ingleses en su capilla funeraria. Nogales, op. cit., pp. 905906.

${ }^{50}$ No hemos hallado más actuaciones en sus dominios, pero es tema pendiente de estudio. Mansilla y Carrión fueron fundaciones posteriores. AHN, Clero, libros 5145 y 9599.

${ }^{51}$ Corell, op. cit., p. 86.

${ }^{52}$ Cañas, op. cit., $\mathrm{n}^{\circ} 15,22,28$ y 42, pp. 48, 59-60, 69-70 y 83-84; Galán Vera, M ${ }^{\text {a }}$ J., El monasterio de Santo Domingo el Real de Toledo, $2^{\mathrm{a}}$ ed. corregida y ampliada por P. Peñas Serrano, Toledo, Monasterio de Santo Domingo el Real, 1999, p. 10.

${ }^{53}$ Cañas, op. cit., $\mathrm{n}^{\circ} 35,45,48,49-51,56,62,66,71,81$, pp. 78-79, 86-90, 93-102, 106-107, $113-$ $114,118-119,122-123,129-131$.

${ }^{54}$ El liderazgo de doña Catalina junto a sus dos parientas monjas en la reconstitución de la rama petrista, en Echevarría, Catalina, p. 78; González de Fauve, Mª E.; Las Heras, I; Forteza, P. de, «Espacios de poder femenino en la Castilla bajomedieval: el caso del linaje de los Castilla», Cuadernos de Historia de España, 2008, vol. 82, pp. 104, 119; Nogales, op. cit., p. 1553.
} 
relaciones femeninas con las que configuró comunidades de interlocutoras en la corte y el monasterio, para algunos autores un verdadero "clan" o "hermandad", además de vincular ambos espacios facultando el empoderamiento de sus moradoras $^{55}$. La comunicación con las monjas de Toledo fue muy estrecha, habitualmente por carta, y en términos de gran afecto ${ }^{56}$.

Parentesco, mediación orante, afecto, servicio y amistad se entrelazaban para unir a la reina y su casa, a la familia real y a la corte, con el monasterio toledano. Éste se acabó convirtiendo en un peculiar espacio cortesano, una especie de capilla de palacio femenina dedicada al bienestar de la reina y la familia real ${ }^{57}$. Doña Catalina hacía saber a las monjas si se encontraba bien, sana y alegre; si algún miembro de la familia estaba enfermo, solicitaba oraciones especiales. Se interesaba por su buen estado, les prestaba cosas de su cámara y capilla, les hacía regalos o compartía médico con ellas. Se favoreció el contacto entre las monjas y las servidoras de la reina: el monasterio podía recibirlas o salir las monjas con ocasión de las visitas de los reyes a Toledo y compartir espacio y actividades ${ }^{58}$. El monasterio constituyó un ámbito de poder que situaba a la reina en posición peculiar: la comunidad le confió la gestión de sus intereses y asuntos económicos y las autoridades dominicas el privilegio sobre la clausura $^{59}$, dos habituales prerrogativas masculinas.

Así respaldada, la reina actuó y se relacionó con Enrique III reivindicando ámbitos de responsabilidad. Sucedió con motivo del nacimiento de Juan II (1405). En la última fase de su embarazo se había hospedado en el palacio de Toro, junto a los dominicos de San Ildefonso, y deseaba la compañía de doña Teresa y doña María. Se evidencia la escasa autoridad del rey en el proceso. Don Enrique escribía a su esposa anunciándole el envío de ambas; como era preciso que ella otorgase licencia, le rogaba que enviase el documento de poder sobre la clausura para mostrárselo a doña Teresa comprometiéndose a devolverlo. También pedía a la priora que fuese a Segovia, pero ella contestaba que necesitaba licencia de sus superiores o de la reina, lo cual le obligó a escribir de nuevo a su esposa. El rey se limitó a ordenar a los oficiales de las poblaciones por donde ambas monjas pasarían que las asistiesen en su viaje ${ }^{60}$.

\footnotetext{
${ }^{55}$ Surtz, R., Writing Women in Late Medieval and Early Modern Spain. The Mothers of Saint Teresa of Avila, Philadelphia, University of Pennsylvania Press, 1995, p. 43; González de Fauve, $\mathrm{M}^{\mathrm{a}}$ E.; Las Heras, I; Forteza, P. de, op. cit., pp. 120-121.

${ }^{56}$ García Rey, C., «La famosa priora doña Teresa de Ayala (su correspondencia íntima con los monarcas de su tiempo)», Boletín de la Real Academia de la Historia, 1930, vol. 96, pp. 702-710; Cañas, op. cit., $\mathrm{n}^{\circ}$ 54, pp. 104-105.

${ }^{57}$ La función de la capilla de palacio era el bienestar espiritual del rey vivo. Nogales, op. cit., p. 176.

${ }^{58}$ Cañas, op. cit., ${ }^{\circ}$ 54-55, 63-64, 83, pp. 104-106, 114-115, 134

${ }^{59}$ Castillo, libro II, fol. 162r; Flórez, E., Memorias de las reinas católicas, Valladolid, Junta de Castilla y León, 2002, vol. 2, p. 710.

${ }^{60}$ Cañas, op. cit., $\mathrm{n}^{\circ}$ 67, 68, 70 y 77, pp. 119-122 y 126-127.
} 
Doña Catalina otorgó la merced de las albricias del nacimiento del infante a la priora doña Teresa y el rey encargó a su mariscal Diego Fernández de Córdoba que realizase las ahumadas en Toro para saber si el recién nacido era varón o hembra. Además, entendió necesario servirse de ambas monjas para imponerse a su esposa comunicándoles su decisión de seleccionar las amas del niño enumerando los requisitos que habían de cumplir. La reina no hizo caso y las nombró por su cuenta. Días después, don Enrique notificaba a las monjas su malestar porque la selección del personal de la casa del infante era competencia suya y les ordenaba decir a doña Catalina que no se entrometiese. Precisamente, en línea con la dimensión simbólica revisada páginas atrás, la reina organizó un importante frente de autoafirmación personal y política en torno al nacimiento, crianza y custodia del heredero y después rey niño: además de querer impedir la injerencia de Enrique III en la elección de las amas, logró monopolizar la custodia y crianza durante la regencia pese a las disposiciones testamentarias de aquel. No parece casual que el nacimiento de Juan II se vinculase al monasterio de Toledo también en lo simbólico, porque cuando allí se celebraba la fiesta de Santo Tomás de Aquino se festejaba el cumpleaños del rey ${ }^{61}$. La función de la reina como madre del rey y transmisora de legitimidad y la del monasterio como vehículo de expresión simbólica y memoria de estos hechos quedaban así explicitadas.

El vínculo con la Orden de Predicadores facultó a la reina para incidir de forma directa en los espacios de espiritualidad femenina, ámbitos sociales en relación con los cuales desarrolló capacidad operativa a fin de actuar a favor de la descendencia de Pedro I creando concepto de linaje, mejorando las condiciones de vida y favoreciéndose a sí misma como sujeto y agente de sus intereses. Las descendientes del rey fueron su primera preocupación y comenzó impulsando su socialización y empoderamiento en los monasterios de dominicas hasta lograr verlas reconocidas como miembros de la familia real. El monasterio fue también espacio de integración de las mujeres Ayala. La reina se sirvió además de la corte para crear un círculo femenino de servicio y apoyo formado por sus parientas bastardas, mujeres Ayala u otras pertenecientes a familias partidarias de Pedro I y de filiación dominica como su valida Leonor López. Al tiempo, favorecía los vínculos entre ambos. Integrando corte y monasterio, se creó un partido propio y femenino.

\subsection{Regente de Castilla}

En los años en que asumió la regencia de Castilla (1406-1418) no realizó nuevas fundaciones, pero apoyó otras creaciones, intensificó presencias y estrechó vínculos. Parece haber buscado la autoafirmación personal, sobre todo

${ }^{61}$ Crónica de Juan II de Castilla, edición de Juan de Mata Carriazo y Arroquia, Madrid, Real Academia de la Historia, 1982, pp. 23 y ss. Cañas, op. cit., no 73-77 y 78-80, pp. 124-129. 
frente a los intentos del corregente, Fernando de Antequera, por anularla políticamente. Si en algún caso se percibe el afán de lograr un equilibrio de fuerzas mediante la acción conventual, predominó otra pauta: la reina aprovechaba las ausencias de su cuñado para estrechar su alianza dominica destacando sus acciones en 1410 o, sobre todo, tras ceñir aquél la corona aragonesa.

En Santa María la Real de Nieva jugó simbólicamente con el nacimiento del rey. El 6 de marzo de 1407, día del segundo cumpleaños de Juan II y muy poco después de la muerte de Enrique III, se otorgaba a instancias suyas en calidad de señora de la villa y patrona del monasterio el importante privilegio de exención a los vecinos. Pretendía favorecer el poblamiento y rematar el diseño del lugar. Todos los que fuesen a morar allí -hidalgos y labradores- hasta un número de doscientos seleccionados por el prior dominico y el concejo, estarían exentos de pechos a perpetuidad; sus ganados tendrían libertad de pasto salvo en las villas de los corregentes y podrían cortar leña donde quisieran, plantar viñas, huertas y labrar pan. Concesiones posteriores manifestaron su afianzamiento como señora y patrona en un contexto de pérdida de poder en el reino fruto de las maniobras políticas de Fernando de Antequera a partir de 1408. Puede ser significativo que aprovechase para ello la ocupación del infante en otros menesteres como la campaña de Granada en 1410. Así, ese año otorgaba otros importantes privilegios al convento de los dominicos, en especial que hiciesen cilla como la que había en Segovia donde monopolizasen la venta de vino recibiendo todos los derechos ${ }^{62}$. Cuando don Fernando ya era rey de Aragón, la reina reforzó su posición y vio confirmadas sus acciones anteriores. En 1414 iniciaba las obras de ampliación de la iglesia de Nieva, hecho consignado en la inscripción de la nave que reza Esta obra de estas capillas mando facer la muy noble e excelente señora dona Catalina reina de Castilla. En probable conexión con esto, desde 1413 otorgaba diversas rentas al convento. En 1415 Benedicto XIII confirmaba la cesión del enclave a los dominicos ${ }^{63}$. Y ese mismo año la reina fundaba su capilla funeraria en Toledo ${ }^{64}$, un espacio propio en el marco del enterramiento colectivo Trastámara.

\footnotetext{
${ }^{62}$ AHN, Clero, leg. 6282; Yuramí, op. cit., p. 310; Sánchez Sierra, op. cit., pp. 24, 34, 123-128.

${ }^{63}$ AHN, Clero, pergs., carp. 1951, $\mathrm{n}^{\circ}$ 14; carp. 1952, no 5; leg. 6282; Yuramí, op. cit., pp. 162, 308-309; Sánchez Sierra, op. cit., pp. 30-33. Caballero Escamilla, S., «Palacios y conventos a finales de la Edad Media: la reina Catalina de Lancáster y Santa María la Real de Nieva», Anales de Historia del Arte, 2012, $\mathrm{n}^{\circ}$ extra 1, El siglo XV hispano y la diversidad de las artes, pp. 267283; Gómez Chacón, D. L., «Reinas y predicadores: el monasterio de Santa María la Real de Nieva en tiempos de Catalina de Lancaster y María de Aragón (1390-1445)», en Teijeira, $\mathrm{M}^{\mathrm{a}} \mathrm{D}$.; Herráez, $\mathrm{M}^{\mathrm{a}} \mathrm{V}$; Cosmen, $\mathrm{M}^{\mathrm{a}} \mathrm{C}$. (coords.), Reyes y prelados: la creación artística en los reinos de León y Castilla (1050-1500), Madrid, Sílex, 2014, pp. 325-340.

${ }^{64}$ Salazar de Mendoza, P., Origen de las dignidades seglares de Castilla y León, Granada, Universidad de Granada, 1998, p. 345; Nogales, op. cit., pp. 1667 ss.
} 
La coincidencia de este interés por singularizarse en el seno de la dinastía y por reforzar sus posiciones de poder en uno de los espacios más peculiares donde ejercía el patronato y el señorío con su papel como regente, plantea interesantes lecturas políticas. El privilegio de exención otorgado a Santa María de Nieva culminaba la formación de una villa especial y remataba un plan político cristiano en el que se subrayaba el peso del convento dominico en el ordenamiento de la villa y en necesario acuerdo con el concejo: los poderes religioso y civil habían de concordarse en la selección de pobladores exentos, que debían ser personas idóneas para conformar una comunidad cristiana fundada en la paz, fe, trabajo y desarrollo económico. No había lugar para el dominio nobiliario. Quizá no fuese casual que Rodrigo Sánchez de Arévalo, oriundo de la villa, escribiese sobre la ciudad ideal ${ }^{65}$.

La intensificación de presencias y vínculos también se percibe en Santo Domingo el Real de Toledo. Doña Catalina mantuvo su actuación benefactora, otorgó numerosos privilegios e intervino en su ampliación edilicia. Fue la responsable de la política de promoción protagonizada por Juan II en sus primeros años. Sobre todo desde 1408 - coincidiendo con la presión política que sufría la reina- se documenta una notable actividad de confirmación de privilegios y nuevas concesiones al linaje Castilla, en especial a doña María, a quien el rey llamaba tia, a doña Teresa y al monasterio. Doña Catalina, presentándose como yo, la syn ventura reyna de Castilla e de Leon, madre del rey e su tutora et regidora de sus regnos, actuaba igualmente por su cuenta ampliando rentas y asegurando su percepción a las dos monjas. Resulta significativo que también favoreciese la ampliación edilicia casi al mismo tiempo que la de Nieva, pues hacia 1413 donaba con este fin unas casas ${ }^{66}$. El monasterio fue nudo de comunicación de la familia real incluyendo a los Trastámara. Doña Catalina podía satisfacer su necesidad de estar informada de lo que ocurría en el reino gracias a estas monjas, que se mantuvieron como grupo de apoyo inamovible frente a las maniobras del infante ${ }^{67}$.

La reina completó su política familiar. Fue en esta fase cuando vinculó la descendencia masculina de Pedro I al cenobio. Mientras don Fernando se dedicaba a la campaña andaluza, escribía a la priora Teresa de Ayala con instrucciones sobre cómo debían sepultar en secreto a don Sancho de Castilla. Ello coincidió con la promoción más visible de otros hijos del rey como Diego de Castilla y quizá con su apoyo a la profesión monástica de más mujeres del linaje $^{68}$. El parentesco entre las monjas de Toledo y las damas y servidoras de la reina pertenecientes a los linajes Castilla y Ayala acabó de anudar los vínculos

\footnotetext{
${ }^{65}$ Así lo ha subrayado Molinero, op. cit., p. 29.

${ }^{66}$ Cañas, op. cit., $\mathrm{n}^{\circ}$ 84-88, 90-91, 98-99, 101-102, 107-108, 111, 120, 125, 138, pp. 134-146, 152-156, 157-159, 163-169, 175-176, 180-181, 192-193.

${ }^{67}$ Echevarría, Catalina, p. 124ss.

${ }^{68}$ Galán, op. cit., pp. 15-16; Cañas, op. cit., p. 15 y n ${ }^{\circ}$ 94-96, 158, pp. 148-151, 213.
} 
entre el cenobio, la familia real y la corte. En estos años acaso se hiciesen más fluidos los contactos; al menos, se documentan entre las validas de la reina y las monjas. Cuando doña Catalina expulsó de la corte a Leonor López, supo que se dirigía a Toledo y ordenó al alcalde mayor detenerla y encerrarla; quizá su destino fuese el monasterio. Hacia 1417, ante los problemas que sufría en la corte, la reina envió allí a su segunda valida, Inés de Torres, pidiendo que la acogiesen como si fuera ella misma o una de sus hijas ${ }^{69}$.

Estos lazos familiares y de servicio trabados en torno al cenobio y con la reina se movilizaron para poner en marcha una nueva fundación dominica en Sevilla, Santa María la Real. En el proceso fundacional intervino el condestable de Castilla Ruy López Dávalos junto a su esposa doña Elvira Vélez de Guevara y Fernández de Ayala, sobrina de doña Teresa de Ayala; ambos solicitaron monjas fundadoras de Toledo. La reina intervino junto a Fernando de Antequera pidiendo licencia fundacional al arzobispo de Sevilla; sólo el infante se dirigió al papa ${ }^{70}$, pero con su participación, la del monasterio toledano y la de una Ayala en este proceso fundacional, la reina se hacía presente en el territorio políticamente controlado por el corregente en unos años, de 1410 a 1412, en los que desarrolló intereses en la zona ${ }^{71}$. De nuevo se percibe un "equilibrio" monástico con el infante, que en estos años desarrollaba su comunicación con las monjas toledanas.

La reina también favoreció a Santo Domingo el Real de Madrid, que mantenía un vínculo ininterrumpido con la corona desde el siglo XIII. Impulsó la confirmación de privilegios, otorgó su protección, benefició a la monja Constanza de Castilla, nieta de Pedro I -a la que llamaba mi parienta-, y contribuyó a la construcción de la nueva capilla mayor a la que más tarde, por orden de Juan II, se trasladarían los restos del rey Pedro. En la rememoración litúrgica de que fue objeto en este monasterio, la reina figuraba integrada en la rama dinástica petrista equiparada a los titulares masculinos de la corona ${ }^{72}$.

\footnotetext{
${ }^{69}$ Cañas, op. cit., $\mathrm{n}^{\mathrm{o}}$ 101, 112, pp. 156, 169-170.

${ }^{70}$ Castillo, op. cit., libro II, fols. 161 y 165; Miura, J. Ma, Frailes, monjas y conventos: las órdenes mendicantes y la sociedad sevillana bajomedieval, Sevilla, Diputación de Sevilla, 1998, pp. 147, 248-249.

${ }^{71}$ Aconsejada por Leonor López, en 1411 se había adjudicado por tres meses la administración de Sevilla, Córdoba y Jaén. Porras Arboledas, P. A., Juan II (1406-1454), Palencia, Diputación Provincial de Palencia; Editorial La Olmeda, 1995, p. 58.

${ }^{72}$ Carrasco Lazareno, $\mathrm{M}^{\mathrm{a}}$ T., La documentación de Santo Domingo el Real de Madrid (12841416), Madrid, Universidad Autónoma de Madrid, 1997, núms. 133-134; Rábade, M $M^{\text {a }}$ P., «Religiosidad y memoria política: las constituciones de la capilla de Pedro I en Santo Domingo el Real de Madrid (1464)», En la España Medieval, 2003, vol. 26, p. 235.
} 


\subsection{El vínculo con la Orden de Predicadores}

La estrecha relación que Catalina de Lancaster entabló con la Orden de Predicadores le sirvió para diferenciarse y prestigiarse, conseguir un importante grupo de apoyo, ampliar sus espacios de poder y maniobra y gestionar sus intereses políticos. Quiso expresamente que su imagen pública se identificase con la espiritualidad dominica: además de enterrarse con el hábito de Santo Domingo, se representó con él en su estatua funeraria ${ }^{73}$. La correspondencia entre la actuación política y la devoción plasmada en el hábito para enterrarse y retratarse no siempre se dio entre los reyes: Sancho IV, gran promotor de los dominicos, se enterró con hábito franciscano y Enrique II eligió el hábito dominico pese a su política franciscanista. Es muy significativo que esta representación pública de la reina, que refrendaba su actuación, se realizase al poco de acceder a la regencia. La figura de Enrique III, enterrado y retratado con el hábito franciscano, resulta complementaria. Reflejo iconográfico de la que parece haber sido práctica política en un matrimonio donde la reina logró abrirse y ver reconocido un espacio propio.

Desde su llegada a Castilla se había rodeado de un entorno dominico. Dominicos fueron casi todos sus confesores, hecho en el que también se diferenció de Enrique III. Está claro el comportamiento proactivo de la reina al no compartir necesariamente los mismos confesores con su marido o porque como regente seleccionó los de Juan II aun incumpliendo el testamento de don Enrique. También logró que fuese a la corte fray Álvaro de Córdoba contra su deseo $^{74}$, hecho indicativo de su instrumentalización de la orden con la posible finalidad de afianzar su "partido" al ser este fraile hermano de su valida Leonor López. En línea similar situaríamos su preferencia por una de las residencias de la corona, el palacio ubicado junto al convento dominico de San Pablo de Valladolid, donde hallaba refugio junto al rey niño, sobre todo en situaciones en que temía ser apartada de él y máxime tras convertirse en señora de la ciudad en 1406. Este convento le brindó un espacio de diálogo político y consejeros letrados para tratar importantes asuntos. Su presencia contrarrestaba al corregente, que también solía hospedarse alli ${ }^{75}$.

Sin duda hubo una relación de mutuo apoyo entre Catalina de Lancaster y los dominicos de la provincia de España. Los favores y privilegios otorgados

\footnotetext{
${ }^{73}$ Flórez, op. cit., pp. 710-711.

${ }^{74}$ Alonso Getino, L. G., «Dominicos españoles confesores de reyes», Ciencia Tomista, 1916, vol. 14, pp. 406-408; López, op. cit., libro II, p. 7; Nogales, op. cit., p. 2008; Corell, op. cit., p. 81; Medrano, Tercera, libro I, pp. 363-365.

${ }^{75}$ Crónica de Juan II, p. 410; Porras, op. cit., p. 58. En 1410 convocaba una asamblea para dirimir los derechos de Juan II y del infante Fernando al trono aragonés: Cañas Gálvez, F. de P., «La diplomacia castellana durante el reinado de Juan II: la participación de los letrados de la cancillería real en las embajadas regias», AEM, 2010, vol. 40, n 2, p. 697. Echevarría, Catalina, p. 133.
} 
por la reina y su promoción de fundaciones de tanto peso como Santa María de Nieva -que, además de ser el primero de los grandes santuarios marianos puestos bajo la custodia de la orden, contó con un palacio real ${ }^{76}$ - tuvieron como contrapartida la concesión de otros por las autoridades dominicas, ya señalados. En su relación con la institución dominica, la reina vio enfatizada su posición de poder como patrona ${ }^{77}$. No extraña que se alinease sin fisuras con el programa antijudío propugnado por Vicente Ferrer en las campañas de predicación que desarrolló en Castilla en 1411 y que dio como fruto la publicación de su famoso ordenamiento sobre judíos y mudéjares ${ }^{78}$. Sin embargo, si como consorte este apoyo dominico contribuía a diferenciarla, en su tiempo de regente debió verse eclipsada por Fernando de Antequera, que optó decididamente por la Orden de Predicadores en su programa de promoción política.

La identificación de doña Catalina con la que era una institución internacional vinculada al papado, así como su activa política de piedad, estrecharon sus lazos con la Sede Apostólica, objetivo que persiguió desde los inicios del reinado. Los papas de Aviñón apoyaron todos sus proyectos fundacionales con licencias e indulgencias respondiendo positivamente a sus demandas. El respaldo pontificio otorgaba a la reina poder suficiente para actuar. Estas conexiones repercutieron en la conformación de los grupos de apoyo a la reina y al papa aviñonés, en los que algunos confesores dominicos fueron promovidos al episcopado. Es un tema amplio que requiere más estudio. Sin obviar otras causas, se entiende la fidelidad de la reina a Benedicto XIII y su prudencia antes de decidir el cambio de obediencias de Castilla ${ }^{79}$.

\section{CONVENTOS Y MONASTERIOS EN LA POLÍTICA DEL REINO}

La actividad monástica y conventual también respondió a las necesidades del reino. Su notable perfil político "público" tuvo mucho que ver con su condición de heredera y con los intereses tejidos en torno a su matrimonio. $\mathrm{Su}$ actuación religiosa revela que fue muy consciente de su responsabilidad histórica y que la ejecutó como "mujer política". La promoción dominica sirvió a la unión y pacificación dinásticas, objetivo representado materialmente en los escudos de los reyes que decoran creaciones como Santa María de Nieva o en las que se consideran sus imágenes probables en la portada de la iglesia visibilizando la unión de las dos ramas dinásticas en un mismo proyecto religioso, hecho refrendado por la construcción de un palacio ${ }^{80}$. En la misma

\footnotetext{
${ }^{76}$ Caballero, «Palacios», p. 274.

${ }^{77}$ Sánchez Sierra, op. cit., p. 34.

${ }^{78}$ Echevarría, Catalina, p. 150; Nieva, «Los dominicos», p. 44.

${ }^{79}$ Sánchez Sierra, op. cit., pp. 129-130; Villarroel, O., «Las mujeres y la paz en la Iglesia: Catalina de Lancáster y el fin del Cisma», e-Spania, 2015, nº 20.

${ }^{80}$ Caballero, «Palacios», pp. 281-282, 271-274.
} 
línea de unión y concordia dinástica cabría entender la complementariedad dominica y franciscana de la pareja real ${ }^{81}$.

Como hemos señalado, la reina trabajó su ascendencia y proyección dinásticas asumiendo con su actuación modelos de comportamiento de los titulares masculinos de la corona. Subrayaba así la línea legítima que la vinculaba a Fernando III manifestando públicamente su continuidad además de rehabilitar la memoria de Pedro I y participaba en los discursos de legitimación que venían esgrimiendo los Trastámara desde Enrique II y en los que Juan I afirmaba el papel de las reinas como transmisoras de derechos ${ }^{82}$. No por casualidad, su madre doña Juana Manuel, como primera reina Trastámara y descendiente de los infantes de la Cerda, había reivindicado también la memoria familiar mediante sus políticas monásticas. En el caso de doña Catalina, no sólo se trató de aportar capital simbólico legitimador enfatizando las líneas de continuidad y visibilizando al rey Pedro. Prestó atención singular a los vínculos familiares y a la relación personal, que potenció en torno a los monasterios. Con ello logró la unión dinástica real, no sólo simbólica, incidiendo directamente sobre los herederos Trastámara, tanto Enrique III como su hermano el infante Fernando, que se reconocieron explícitamente como parientes y descendientes de Pedro I. Además de ello, logró legitimación para la descendencia bastarda de éste.

Las fundaciones y promociones religiosas de la reina contribuyeron a unir simbólicamente cuerpo femenino y palabra a favor de la concordia dinástica, política y social, objetivo que ella consideró su misión tal y como reza su epitafio $^{83}$ y que era el fundamento de la nueva política espiritual femenina ya mencionada. Pero, además, con ellas la reina incidió también en el fortalecimiento de la corona colaborando con el rey. No sólo en dimensión representativa por su capacidad propagandística como lenguaje o expresión de la institución y de un determinado plan político. Pues la función de la reina fue también plasmarlo en la realidad, siquiera a pequeña escala, ayudando y complementando políticamente al rey.

Al crear espacios religiosos en lugares que no estaban bajo la directa jurisdicción real, doña Catalina garantizaba la presencia de la corona en ámbitos controlados por la nobleza o los grandes concejos. Tanto en Mayorga como en Nieva, esta irrupción, sintonizada con el fortalecimiento de la institución

\footnotetext{
${ }^{81}$ Olivera, «Felipa», p. 377; Fernández de Córdova, op. cit., p. 126.

${ }^{82}$ Suárez Bilbao, op. cit., pp. 131. En las cortes de Segovia (1386), Juan I se refirió a su madre, doña Juana Manuel: como descendiente de los infantes de la Cerda, proporcionó a su marido e hijos los derechos al trono. Suárez Fernández, L., Historia del reinado de Juan I de Castilla, I: Estudio, Valladolid, Universidad de Valladolid, 1977, p. 256.

${ }^{83}$ Por la qual es paz y concordia puesta para siempre. Arco, R. del, Sepulcros de la casa real de Castilla, Madrid, CSIC, 1954, p. 327. Aniz, C.; Callejo, R., op. cit., p. 82.
} 
monárquica promovido por Enrique III $^{84}$, pudo verse facilitada por ser fruto de la conducta piadosa de una reina. Porque si Juan I y Enrique III venían erosionando a la poderosa comunidad segoviana enajenando terrenos para cederlos a instituciones religiosas como la cartuja de El Paular, la acción de la reina iba más allá en su creación de una villa exenta. Ello generó un duro enfrentamiento con el concejo de Segovia finalmente resuelto a favor de la monarca $(1395)^{85}$.

La corona, pacificada por la unión de las dos líneas dinásticas, se ponía al servicio de la paz social. Mayorga y Nieva fueron dos fundaciones con destacado perfil social y popular en su capacidad para conectar con súbditos de toda procedencia. La fama de santidad, las devociones novedosas o el aprovechamiento de lugares milagrosos garantizaban su irradiación. La concordia pública se entrelazaba con la palabra predicadora de la orden y la difusión del cristianismo en el proyecto reginal. En Mayorga respondía además a las acciones de abuso por parte de la nobleza ofreciendo un contramodelo de orden y paz sustentado por la monarquía frente al particularismo nobiliario. Debió incidir también poderosamente el problema judío, que había estallado con crudeza poco antes. En la villa había comunidad judía y, aunque junto al monasterio no hubo frailes ${ }^{86}$, su itinerancia facilitaba presencias; su advocación, con la que se rememoraba a un gran predicador e inquisidor, era reclamo simbólico. La reina desarrolló su política conventual en poblaciones con presencia judía y sin duda quiso atajar el problema; indicio de ello sería el programa iconográfico antijudío de la iglesia de Nieva ${ }^{87}$. Sin embargo, este objetivo de predicación antijudía, notoriamente político, no ha sido destacado por la cronística dominica entre sus intenciones fundacionales y sí muy subrayado en Fernando de Antequera.

Respecto a la orientación religiosa de los reinados, se ha señalado que el impulso de los Trastámara a la Orden de Predicadores en el paso del siglo XIV al $\mathrm{XV}$ tuvo que ver con el "aspecto fundamentalista" contra las minorías de judíos y mudéjares que contenía el programa regeneracionista de la nueva dinastía subrayando el protagonismo de Fernando de Antequera. Sus creaciones dominicas tuvieron como objetivo destacado la predicación antijudía: impulsó conventos ya existentes -Peñafiel- y fundó otros en poblaciones significativas de sus estados como Villalón, donde instaló a los dominicos en 1402 para que evangelizasen a los judíos, o Medina del Campo refundando en 1406 un convento que trasladó intramuros con la misma pretensión. También apoyó el

\footnotetext{
${ }^{84}$ Así lo han venido subrayando diversos autores: Sánchez Sierra, op. cit., pp. 5-6, 15; Molinero, op. cit., p. 8; Echevarría, Catalina, p. 83.

${ }_{85}^{85}$ Arnanz, op. cit., p. 81; Sánchez Sierra, op. cit., pp. 22-24; Molinero, op. cit., p. 8.

${ }^{86}$ El duque de Benavente se había apropiado de Mayorga y en 1394 firmó la paz. Aniz, C.; Callejo, R., op. cit., p. 57, 38, 40; Echevarría, «Dinastía», p. 75.

${ }^{87}$ Caballero, «Palacios», pp. 275ss.
} 
traslado intramuros de los dominicos de Toledo (1407) y solicitó a Juan II la advocación de San Pedro Mártir el Real. Había previsto una fundación femenina en Medina que no pudo realizar por ceñir la corona aragonesa y que culminó su esposa $^{88}$.

Sin embargo, fue Catalina de Lancaster quien inició las fundaciones dominicas y a ella se debió la renovada alianza entre la monarquía castellana y la Orden de Predicadores. También diseñó los modelos fundacionales que en buena medida siguió después su cuñado. Don Fernando parece haberse inspirado en sus formas de actuar y en su interés por situar los centros de espiritualidad intramuros, por difundir la advocación de San Pedro Mártir o, mediante esta actividad fundacional y benefactora, por hacerse visible en la primera línea política del reino: precisamente, comenzó a fundar mientras engrandecía su casa y creaba un partido propio. El infante se ganó así también el apoyo de la Orden de Predicadores, que tan importante fue, sobre todo en la persona de Vicente Ferrer, para conseguir el trono de Aragón. Incluso, la devoción mariana, sobre la que doña Catalina había construido una parte muy importante de su imagen pública, fue enérgicamente reivindicada por el infante en esta misma dimensión. Aun considerando otros posibles intereses, no podemos dejar de preguntarnos si don Fernando no optó decididamente por los dominicos para neutralizar a la reina en su propio terreno.

\section{BIBLIOGRAFÍA}

Aguadé Nieto, Santiago, «Alfonso X y las órdenes mendicantes», Saxonia Franciscana, 1998, vol. 10, pp. 277-302.

Alonso Getino, Luis, «Dominicos españoles confesores de reyes», Ciencia Tomista, 1916, vol. 14, pp. 374-450.

Aniz Iriarte, Cándido; Callejo de Paz, Rufino, Real monasterio de San Pedro Mártir de Mayorga. Fundación de la reina Catalina de Lancaster, Salamanca, San Esteban, 1994.

Arco y Garay, Ricardo del, Sepulcros de la casa real de Castilla, Madrid, CSIC, 1954.

Arnanz Ruiz, Carlos, Santa María la Real de Nieva, Santa María la Real de Nieva, Ayuntamiento, 1972.

\footnotetext{
${ }^{88}$ López, Tercera, libro II, p. 28; Medrano, Tercera, libro I, pp. 29-31, 63-64; Nieva, «Los dominicos», pp. 37, 39-40, 42, 47; Nieva Ocampo, G., «Monarquía y clero regular: los dominicos de Castilla durante el reinado de Enrique III y la minoría de Juan II», Cuadernos de Historia de España, 2011-2012, 85, pp. 525-542.
} 
Beltrán de Heredia, Vicente, «Noticias y documentos para la biografía del cardenal Juan de Torquemada», Archivum Fratrum Praedicatorum, 1960, 30, pp. 53-148.

Børressen, Kari Elisabeth, Le madri della Chiesa. Il Medioevo, Napoli, M. D’Auria Editore, 1993.

Caballero Escamilla, Sonia, «El claustro de Santa María la Real de Nieva: imágenes y contextos», Cuadernos de Arte de la Universidad de Granada, 2011, n 42, pp. 5-18.

Caballero Escamilla, Sonia, «Palacios y conventos a finales de la Edad Media: la reina Catalina de Lancáster y Santa María la Real de Nieva», Anales de Historia del Arte, 2012, $\mathrm{n}^{\circ}$ extra 1, El siglo XV hispano y la diversidad de las artes, pp. 267-283.

Cañas Gálvez, Francisco de Paula, «La diplomacia castellana durante el reinado de Juan II: la participación de los letrados de la cancillería real en las embajadas regias», Anuario de Estudios Medievales, 2010, vol. 40, $\mathrm{n}^{\circ}$ 2, pp. 691-722.

Cañas Gálvez, Francisco de Paula, Colección diplomática de Santo Domingo el Real de Toledo. Documentos reales I (1249-1473), Madrid, Sílex, 2010.

Carrasco Lazareno, María Teresa, La documentación de Santo Domingo el Real de Madrid (1284-1416), Madrid, Universidad Autónoma de Madrid, 1997.

Casillas García, José Antonio, El convento de San Pablo de Burgos. Historia y arte, Salamanca, San Esteban, 2003.

Castillo, Hernando del, Segunda parte de la Historia general de Santo Domingo $y$ de su Orden de Predicadores, Valladolid, por Francisco Fernandez de Cordoua: véndese en casa de Antonio Coello y a su costa, 1612.

Corell Ruiz, Luis, Una copia del testamento de Catalina de Lancaster, Valencia, Instituto Valenciano de Estudios Históricos, 1952.

Crónica de Juan II de Castilla, edición de Mata Carriazo y Arroquia, Juan de, Madrid, Real Academia de la Historia, 1982. 
Echevarría, Ana, Catalina de Lancaster. Reina regente de Castilla (1372-1418), Hondarribia, Editorial Nerea, 2002.

Echevarría, Ana, «Dinastía: reinas mecenas en los albores del Humanismo», en Serrano de Haro, Amparo; Alegre, Esther (coords.), Retrato de la mujer renacentista, Madrid, UNED, 2012, pp. 67-90.

Fernández de Córdoba Miralles, Álvaro, «El cordón y la piña. Signos emblemáticos y devociones religiosas de Enrique III y Catalina de Lancaster (1390-1418)», Archivo Español de Arte, 2016, 89, pp. 113-130.

Flórez, Enrique, Memorias de las reinas católicas, Valladolid, Junta de Castilla y León, vol. 2, 2002.

Galán Vera, María Jesús, El monasterio de Santo Domingo el Real de Toledo, $2^{\mathrm{a}}$ ed. corregida y ampliada por P. Peñas Serrano, Toledo, Monasterio de Santo Domingo el Real, 1999.

García Rey, Comandante, «La famosa priora doña Teresa de Ayala (su correspondencia íntima con los monarcas de su tiempo)», Boletín de la Real Academia de la Historia, 1930, vol. 96, pp. 685-773.

Gómez Chacón, Diana Lucía, «Reinas y predicadores: el monasterio de Santa María la Real de Nieva en tiempos de Catalina de Lancaster y María de Aragón (1390-1445)», en Teijeira, María Dolores; Herráez, María Victoria; Cosmen, María Concepción (coords.), Reyes y prelados: la creación artística en los reinos de León y Castilla (1050-1500), Madrid, Sílex, 2014, pp. 325-340.

Gómez Chacón, Diana Lucía, «Apariciones marianas y renovación monástica en la Castilla bajomedieval: Guadalupe y Santa María la Real de Nieva», en García de Cortázar, José Ángel; Teja, Ramón (coords.), Los monasterios medievales en sus emplazamientos: lugares de memoria de lo sagrado, Aguilar de Campóo, Fundación de Santa María la Real, 2016, pp. 211-244.

González, Julio, Reinado y diplomas de Fernando III, Córdoba, Monte de Piedad y Caja de Ahorros de Córdoba, 1983, vol. 2.

González Cristóbal, Margarita, Monasterio de Santa Clara de Tordesillas (1316-1936), Madrid, Patrimonio Nacional, 1987. 
González de Fauve, María Estela; Las Heras, Isabel; Forteza, Patricia de, «Espacios de poder femenino en la Castilla bajomedieval: el caso del linaje de los Castilla», Cuadernos de Historia de España, 2008, vol. 82, pp. 99-122.

Graña Cid, María del Mar, «¿Favoritas de la corona? Los amores del rey y la promoción de la Orden de Santa Clara en Castilla (ss. XIII-XIV)», Anuario de Estudios Medievales, 2014, vol. 44, nº 1, pp. 179-213.

Graña Cid, María del Mar, «Mariología, reginalidad y poder en Isabel de Villena. Una teoría política femenina del siglo XV», Mirabilia, 2016, 22, pp. 96-127.

Graña Cid, María del Mar, «The Mendicant Orders and the Castilian Monarchy: The Reign of Ferdinand III», en García Serrano, Francisco (ed.), The Friars in Medieval Spain, (en prensa).

Graña Cid, María del Mar, «Religión y política femenina en el Renacimiento castellano. Lecturas simbólicas de Teresa Enríquez», en Lorenzo, Josemi; Cerrada, Ana Isabel (eds.), De los símbolos al orden simbólico femenino (ss. IV-XVII), Madrid, A. C. Al-Mudayna, 1998, pp. 145-172.

Graña Cid, María del Mar, «El nuevo Evangelio de las mujeres. Aportaciones mariológicas visionarias de Brígida de Suecia y Juana de la Cruz», ponencia en IV Colloquium Studium Medievale, Universitat de Girona, 2010 .

Herrera Casado, Antonio, Monasterios medievales de Guadalajara, Guadalajara, Aache Ediciones, 1997.

Jardin, Jean-Pierre, «Le rôle politique des femmes dans la dynastie Trastamare», e-Spania, 2006.

Jiménez Duque, Baldomero, «Santa Brígida de Suecia (+1373) y los jerónimos españoles», Yermo, 1974, 12, pp. 3-14.

López, Juan, Tercera parte de la historia general de Sancto Domingo y de su Orden de Predicadores, Valladolid, por Francisco Fernandez de Cordoua y a su costa, 1613. 
Martín Prieto, Pablo, «Sobre la promoción regia de la orden franciscana en la Corona de Castilla durante el primer reinado Trastámara», Hispania Sacra, 2007, vol. 59, n 119, pp. 51-83.

McNamara, Jo Ann, «Living Sermons: Consecrated Women and the Conversion of Gaul», en Nichols, John A.; Shank, Lillian T. (eds.), Medieval Religious Women: Peaceweavers, Kalamazoo, Cistercian Publications, 1987, vol. 2, pp. 19-37.

Medrano, Manuel José de, Historia de la Provincia de España de la Orden de Predicadores. Segunda parte, Madrid, en la imprenta de Geronimo Roxo, 1729.

Medrano, Manuel José de, Historia de la Provincia de España de la Orden de Predicadores. Tercera parte, Madrid, en la imprenta de Alfonso de Mora, 1734.

Miura, José María, Frailes, monjas y conventos: las órdenes mendicantes y la sociedad sevillana bajomedieval, Sevilla, Diputación de Sevilla, 1998.

Molinero Rodríguez, Felipe, La ciudad medieval de Santa María la Real de Nieva (Segovia), Segovia, Santa María la Real de Nieva, 2001.

Morena, Áurea de la (coord.), Castilla-La Mancha, La España Gótica, vol. 13, Madrid, Encuentro, 1998.

Nieto Soria, José Manuel, «Franciscanos y franciscanismo en la política y en la corte de la Castilla Trastámara», Anuario de Estudios Medievales, 1990, vol. 20, pp. 109-132.

Nieva Ocampo, Guillermo, «'Reformatio in membris': conventualidad y resistencia a la reforma entre los dominicos de Castilla en el siglo XV», En la España Medieval, 2009, vol. 32, pp. 297-341.

Nieva Ocampo, Guillermo, «Los dominicos en Castilla. La génesis de una corporación privilegiada en la Baja Edad Media», en Nieva, Guillermo; Benito, Silvano G. A.; Navarro, Andrea Mariana (coords.), Servir a Dios y servir al rey: el mundo de los privilegiados en el ámbito hispánico (ss. XIII-XVIII), Salta, Mundo Gráfico, 2011, pp. 13-48. 
Nieva Ocampo, Guillermo, «Monarquía y clero regular: los dominicos de Castilla durante el reinado de Enrique III y la minoría de Juan II», Cuadernos de Historia de España, 2011-2012, 85, pp. 525-542.

Nogales Rincón, David, La representación religiosa de la monarquía castellano-leonesa: la capilla real (1252-1504), (Tesis Doctoral inédita), Universidad Complutense de Madrid, 2009.

Olivera Serrano, César, Beatriz de Portugal. La pugna dinástica AvísTrastámara, Santiago de Compostela, CSIC, 2005.

Olivera Serrano, César, «Devociones regias y proyectos políticos: los comienzos del monasterio de San Benito el Real de Valladolid (13901430)», Anuario de Estudios Medievales, 2013, vol. 43, n 2, pp. 799832.

Olivera Serrano, César, «Felipa y Catalina de Láncaster: religiosidad y relato historiográfico», AEM, 2016, 46/1, pp. 361-391.

Orejón Calvo, Anacleto, Historia del convento de Santa Clara de Astudillo, Palencia, Imprenta de la Casa de Expósitos y Hospicio Provincial, 1917.

Pérez Vidal, Mercedes, "“Uniformitas vs diversitas" en los monasterios femeninos de la Orden de Predicadores en Castilla (siglos XIII-XV)», Territorio, Sociedad y Poder, 2013, vol. 8, pp. 133-152.

Porras Arboledas, Pedro Andrés, Juan II (1406-1454), Palencia, Diputación Provincial de Palencia - Editorial La Olmeda, 1995.

Rábade, María del Pilar, «Religiosidad y memoria política: las constituciones de la capilla de Pedro I en Santo Domingo el Real de Madrid (1464)», En la España Medieval, 2003, vol. 26, pp. 227-261.

Rivera Garretas, María-Milagros, Textos y espacios de mujeres. Europa, siglo $I V-X V$, Barcelona, Icaria, 1990.

Salazar de Mendoza, Pedro, Origen de las dignidades seglares de Castilla y León, Granada, Universidad de Granada, 1998.

Sánchez Sierra, Antonio, El monasterio de Santa María la Real de Nieva, Segovia, Caja de Ahorros y Monte de Piedad de Segovia, 1983. 
Sánchez Sierra, Antonio, Guía del monasterio de Santa María la Real de Nieva, Segovia, Asociación Cultural Santa María, 2004.

Silleras Fernández, Nùria, «Queenship en la Corona de Aragón en la Baja Edad Media: estudio y propuesta terminológica», La Corónica: A Journal of Medieval Hispanic Languages, Literatures \& Cultures, 2003, vol. 32, $\mathrm{n}^{\circ}$ 1, pp. 119-133.

Suárez Bilbao, Fernando, Enrique III (1390-1406), Palencia, Diputación Provincial - La Olmeda, 1994.

Suárez Fernández, Luis, Historia del reinado de Juan I de Castilla, I: Estudio, Valladolid, Universidad de Valladolid, 1977.

Surtz, Ronald, Writing Women in Late Medieval and Early Modern Spain. The Mothers of Saint Teresa of Avila, Philadelphia, University of Pennsylvania Press, 1995.

Villarroel, Óscar, «Las mujeres y la paz en la Iglesia: Catalina de Lancáster y el fin del Cisma», e-Spania, 2015, $\mathrm{n}^{\circ} 20$

Yuramí, Antonio Miguel, Historia de la aparición de la taumaturga ymagen de Nuestra Señora la Soterraña de Nieva, Madrid, Galileo, 54, 1995. 